\title{
Influence of Bioregulators on Latex Yield and Proteolytic Activity of Papain Extracted from Field-grown TNAU Papaya CO. 8 under the Natural Incidence of Papaya Ring Spot Virus
}

\author{
Akino $\mathrm{A}^{1}$, Soorianathasundaram $\mathrm{K}^{1 *}$, Paramaguru $\mathrm{P}^{2}$, Jeyakumar $\mathrm{P}^{3}$ and Muthulakshmi $\mathrm{P}^{4}$ \\ ${ }^{1 *}$ Department of Fruit Science, Tamil Nadu Agricultural University, Coimbatore-641 003 \\ ${ }^{2}$ Horticultural College and Research Institute for Women, Tamil Nadu Agricultural University, Thiruchirappalli-620 027 \\ ${ }^{3}$ Department of Crop Physiology, Tamil Nadu Agricultural University, Coimbatore-641 003 \\ ${ }^{4}$ Department of Medicinal and Aromatic Crops, Tamil Nadu Agricultural University, Coimbatore-641 003
}

\begin{abstract}
The cultivation of papaya for both fruits and commercial papain extraction drastically suffers often due to the devastating incidence of papaya ringspot virus disease. The present study aimed to find out whether the papain yield and quality are influenced when bioregulators are applied to manage papaya ring spot virus (PRSV) incidence or as a measure to limit the height of the crop in TNAU Papaya CO.8 variety grown in the open field with the natural incidence of PRSV. Three growth retardants [250 ppm of prohexadione calcium $\left(G_{2}\right)$, $500 \mathrm{ppm}$ of mepiquat chloride $\left(\mathrm{G}_{3}\right)$ and $500 \mathrm{ppm}$ of chlormequat chloride $\left(G_{4}\right)$ ] and three stress tolerance promoting bioregulators [100 ppm of methyl jasmonate $\left(\mathrm{S}_{2}\right), 100 \mathrm{ppm}$ of salicylic acid $\left(\mathrm{S}_{3}\right)$ and $0.6 \mathrm{~g} / \mathrm{I}$ of strobilurins $\left.\left(\mathrm{S}_{4}\right)\right]$ were employed in the study. Water spray $\left(G_{1}\right.$ and $\left.S_{1}\right)$ was kept as control. The treatments were imposed at $4^{\text {th }}$ and $8^{\text {th }}$ months after planting. The growth retardants were initially sprayed and, in the subsequentweek ,the stress tolerance promoting bioregulators were sprayed as per the recommended doses. Among the combinations tried, spraying $250 \mathrm{ppm}$ of prohexadione calcium followed by water spray $\left(\mathrm{G}_{2} \mathrm{~S}_{1}\right)$ a week later recorded the lowest plant height $(140.79 \mathrm{~cm})$ at the time of fruiting. The treatment combination $\mathrm{G}_{2} \mathrm{~S}_{2}$ involving $250 \mathrm{ppm}$ of prohexadione calcium and $100 \mathrm{ppm}$ of methyl jasmonate registered a higher number of fruits (42.17). The combination of $250 \mathrm{ppm}$ of prohexadione calcium along with $100 \mathrm{ppm}$ of salicylic acid $\left(G_{2} S_{3}\right)$ was found to be the most effective combination to manage PRSV without compromising papain production and to enhance the proteolytic activity significantly (44378.36 $\mathrm{TU} \mathrm{g}^{-1}$ ) as compared to other combinations. The treatment combination of $500 \mathrm{ppm}$ of mepiquat chloride and $100 \mathrm{ppm}$ of salicylic acid $\left(\mathrm{G}_{3} \mathrm{~S}_{3}\right)$ favored higher dry latex yield apart from a significant reduction in PRSV symptoms. Both these treatment combinations $\left(\mathrm{G}_{2} \mathrm{~S}_{3}\right.$ and $\mathrm{G}_{3} \mathrm{~S}_{3}$ ) merit due consideration in PRSV management for commercial fruit and papain production in papaya.
\end{abstract}

Keywords: Papaya; Bioregulators; Prohexodione calcium; Mepiquat chloride; Salicylic acid; Methyl jasmonate; Papain; Latex yield; Proteolytic activity

\section{INTRODUCTION}

Papaya, commercially grown for its nutritious fruits and besides, it is an excellent source of a proteolytic enzyme 'papain' present in the latex of unripe fruits. The latex contains a mix of proteolytic enzymes including papain, chymopapain A and B, endopeptidase papain III, endopeptidase papain IV and endopeptidase papain omega (Azarkan et al., 2003). Papain is a single-chain non-glycosylated polypeptide of 212 amino acids (23, $429 \mathrm{Da})$ containing three disulfide bonds (Mamboya, 2012).
Papain is used in many pharmaceutical, food and beverage, meat, dairy, textile, photographic, optical, tanning, cosmetic, detergent and leather industries, and there is a growing demand for the papain (Shouket et al., 2020).

Papaya crop is often devastated by the disease caused by PRSV, in most countries where it is commercially grown. In India also, PRSV disease significantly affects fruit and papain production leading to substantial economic losses (Mishra et al., 2019). The symptoms of PRSV include distortion 
of young leaves, development of a shoestring appearance, stunted plant and ring spots on the surface of the fruit (Gonsalves et al., 2010). The crop loss due to PRSV can be to the extent of 70 to $95 \%$ (Singh and Shukla, 2009). Since there is no genetic resistance to PRSV in presently available commercial papaya varieties grown in India, the management of PRSV with bioregulators is a possible alternative option as the growth regulators can modulate the physiology of the crop to overcome the cellular stress caused by PRSV. When plants are tall, access to fruits for papain extraction is often difficult and growth retardants may help limit the crop height. Growth manipulation to reduce the height and overcome stresses caused by invasive pathogens have been earlier attempted in many crops (Abdi et al., 2016; Mouca et al., 2013; Le Roux and Barry, 2010), but such studies are lacking in papaya. The present study was taken up to find out whether the papain yield and quality are compromised when growth retardant bioregulators are used in combination to manage plant height and to promote physiological tolerance to PRSV.

\section{MATERIAL AND METHODS}

The trial was carried out at the University orchard, Horticultural College and Research Institute, Tamil Nadu Agricultural University, Coimbatore, Tamil Nadu. Among the papaya varieties released from Tamil Nadu Agricultural University, the variety TNAU Papaya CO. 8 was used in this study, as it is gaining importance among the growers. It is a dioecious variety with red pulp and having a high yield potential of $200-220 \mathrm{t} / \mathrm{ha}$. This variety is recommended for both table purposes and industrially valued papain.

\section{Treatment details}

For the study, three growth retardants were considered as one factor and three stress regulating bioregulators were considered as another factor. The growth retardants used for the study were 250 ppm of prohexadione calcium $\left(G_{2}\right), 500$ ppm of mepiquat chloride $\left(G_{3}\right)$ and 500 ppm of chlormequat chloride $\left(G_{4}\right)$ and the three stress tolerance promoting bioregulators viz., $100 \mathrm{ppm}$ of methyl jasmonate $\left(\mathrm{S}_{2}\right), 100 \mathrm{ppm}$ of salicylic acid $\left(\mathrm{S}_{3}\right)$ and $0.6 \mathrm{~g} / \mathrm{I}$ of strobilurins $\left(\mathrm{S}_{4}\right)$. In both the factors, water spray $\left(G_{1}\right.$ and $\left.S_{1}\right)$ was kept as control. The bioregulator treatments were applied as a foliar spray at the fourth and eighth months after transplanting as per the treatment details. Initially, growth retardants were sprayed as per the treatment details and one week after the application, stress tolerance promoting bioregulators were sprayed along with water spray as the control for both the factors.

\section{Papain extraction}

The papaya latex (crude papain) was extracted from each treatment of papaya variety TNAU papaya C0.8 at 3-4 days intervals commencing from 70 days to 90 days after fruit set. The latex was collected between 6.30 and $8.30 \mathrm{am}$, in polythene covers to quantify the wet latex yield. To the fresh latex, potassium metabisulphite at the concentration of $0.5 \%$ was added to avoid the loss of enzyme activity and was shade dried. After drying, the crude papain was weighed as dry latex and stored in the freezer at $-20{ }^{\circ} \mathrm{C}$.

\section{Observations recorded}

\section{Plant height (cm)}

The height of the plant was measured $15 \mathrm{~cm}$ from ground level to the terminal of the crown at the time of fruiting and expressed in centimeters.

\section{First bearing height $(\mathrm{cm})$}

The height of the plant from the $15 \mathrm{~cm}$ level to the height at which the first mature fruit appeared was measured as first bearing height and expressed in centimeters.

\section{Number of fruits/tree}

The total number of fruit set on the plant was counted when the first harvest commenced and expressed in numbers.

\section{Fruit length (cm)}

The length of the fruit was measured from the stylar end to the pedicel end of the fruit along the curve by using a measuring tape and expressed in centimeters.

\section{Fruit circumference (cm)}

The circumference of the fruit was measured at the midpoint of the length along the curve by using a thread and expressed in centimeters.

\section{PRSV incidence}

Papaya Ring Spot Virus (PRSV) disease incidence was recorded using the following score chart (Table 1), having six delineating scores (Dhanam, 2006).

\section{Table 1. Symptoms and score chart of PRSV}

\begin{tabular}{|c|c|c|}
\hline S. No & Description of the symptoms & Score \\
\hline 1. & No symptoms & 0 \\
\hline 2. & $\begin{array}{l}\text { Mild mosaic (or) oily spots, streaks on the petiole } \\
\text { (or) stem, oily spots on fruits }\end{array}$ & 1 \\
\hline 3. & $\begin{array}{l}\text { Mild mosaic and oily streaks/ spots on petiole/ stem } \\
\text { and ring spots on fruits }\end{array}$ & 3 \\
\hline 4. & $\begin{array}{l}\text { Oily spots/ streaks on petiole (or) stem (or) ring } \\
\text { spots on fruits }\end{array}$ & 5 \\
\hline 5. & $\begin{array}{l}\text { Oily spots/streaks on petioles, stem or on fruits } \\
\text { (ring spots), severe mosaic or blistening on leaves } \\
\text { and leaf deformation + severe leaf reduction / mild } \\
\text { fruit deformation with ring spots }\end{array}$ & $\begin{array}{l}S \\
S \\
d\end{array}$ \\
\hline 6. & $\begin{array}{l}\text { Oily spots/ streaks on petiole or stem and shoe string } \\
\text { formation or severe fruit development with ring spots } \\
\text { and stunted plants }\end{array}$ & 9 \\
\hline
\end{tabular}


The disease severity was calculated using the following formula:

(Total score of all plants/Total

PRSV $($ per cent $)=$ number of plants $)$

$$
x(100 / \text { max score) }
$$

\section{Wet latex yield (g)}

The fresh latex collected from each fruit was weighed using a weighing balance and expressed in grams.

\section{Dry latex yield (g)}

The wet latex was then allowed to dry in partial shade for 7-8 hrs. The dried latex (crude papain) was then collected, weighed, and expressed in grams.

\section{Papain enzyme activity (TU $\mathbf{m g}^{-1}$ )}

The papain activity was assayed using the method described by Weissler and Garza (1965). In this method, casein was used as substrate and the amount of tyrosine released from a standard casein solution was measured and reported as tyrosine units per gram of papain.

\section{Statistical analysis}

The experiment was laid out in Factorial Randomized Block Design (FRBD) with four treatments in each of the two factors (16 treatment combinations + one absolute control) and replicated thrice. The mean effects were compared after subjecting the data collected by Factorial ANOVA test with SPSS 16.0 software and critical differences were worked out at five percent probability level.

\section{RESULTS AND DISCUSSION}

\section{Influence of bioregulators on plant height (cm) and first bearing height $(\mathrm{cm})$ of TNAU Papaya C0.8}

Lower plant height is advantageous for many cultural operations, including spraying of micronutrients, plant protection chemicals, harvesting and for papain extraction. In the present study, significant differences were observed in plant height and for first fruit bearing height as well due to the main effects of growth retardant treatments but not for main effects of stress tolerance promoting bioregulators. However, the interaction effects were significant. When the main effects of growth retardants are considered, 250 ppm of prohexadione calcium $\left(\mathrm{G}_{2}-147.54 \mathrm{~cm}\right)$ and 500 ppm of chlormequat chloride $\left(G_{4}-147.05 \mathrm{~cm}\right)$ recorded the lowest plant height. Mepiquat chloride $\left(G_{3}\right)$ also resulted in restricting plant height (152.32 $\mathrm{cm})$ as compared to control $\left(\mathrm{G}_{1}-173.35 \mathrm{~cm}\right.$ ) (Figure 1). Among the combinations, spraying of $250 \mathrm{ppm}$ of prohexadione calcium followed by water spray $\left(\mathrm{G}_{2} \mathrm{~S}_{1}\right)$ recorded the lowest plant height $(140.79 \mathrm{~cm})$ at the time of fruiting (Table 4). Higher plant heights were observed with spraying of stress tolerance promoting bioregulators alone without growth retardants $\left(\mathrm{G}_{1} \mathrm{~S}_{1}\right.$ - $171.25 \mathrm{~cm}, \mathrm{G}_{1} \mathrm{~S}_{2}-174.37 \mathrm{~cm}, \mathrm{G}_{1} \mathrm{~S}_{3}-175.48 \mathrm{~cm}$ and $\mathrm{G}_{1} \mathrm{~S}_{4}-172.30 \mathrm{~cm}$ ).

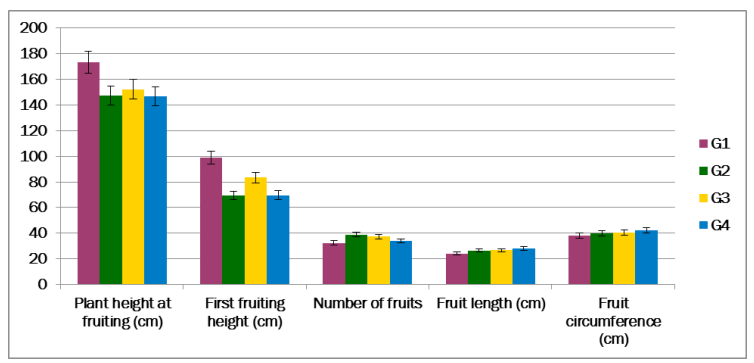

Figure 1. Main effects of growth retardants on plant morphological and fruit physical parameters

Like plant height, first fruiting height or bearing height is an important trait in papaya cultivation as it directly corresponds to the early harvest of fruits and economic life of the plantation. When the main effects of growth retardants are considered, 250 ppm of prohexadione calcium $\left(G_{2}-69.44 \mathrm{~cm}\right)$ and 500 ppm of chlormequat chloride $\left(G_{4}-69.49 \mathrm{~cm}\right)$ recorded lower fruiting heights (Figure 1 ). When both the factors are combined, $500 \mathrm{ppm}$ of chlormequat chloride along with $100 \mathrm{ppm}$ of salicylic acid $\left(\mathrm{G}_{4} \mathrm{~S}_{3}\right.$ - $68.17 \mathrm{~cm}$ ) and $250 \mathrm{ppm}$ of prohexadione calcium followed by water spray $\left(G_{2} S_{1}-68.43 \mathrm{~cm}\right)$ recorded significantly lower fruiting height as compared to the higher bearing height $(102.71 \mathrm{~cm})$ of absolute control (Table 2).

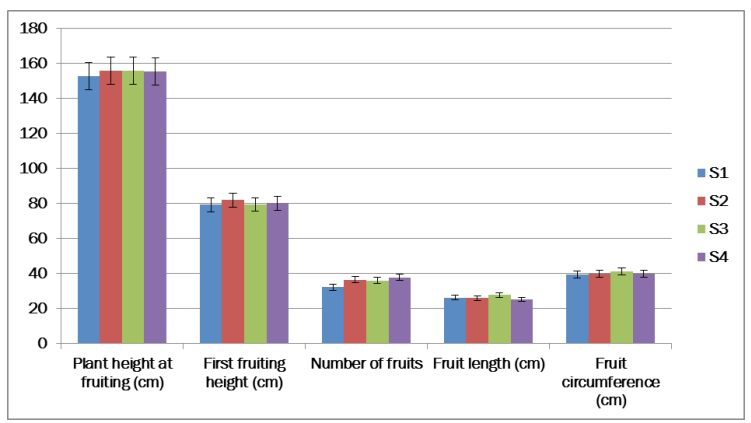

Figure 2. Main effects of stress tolerance promoting bioregulators on plant morphological and fruit physical parameters

The reason for height reduction in the treatment involving $G_{2}$ can be attributed to the action of prohexadione calcium, a gibberellin biosynthesis inhibitor that acts as a co-substrate for catalyzing hydroxylations involved in the late stages of GA biosynthesis. This retardant has been reported to mainly target an enzyme $3 b$-hydroxylase, which helps in the conversion of inactive $\mathrm{GA}_{20} / \mathrm{GA}_{9}$ into highly active $\mathrm{GA}_{1} / \mathrm{GA}_{4}$, leading to reduced plant height and shoot length (Kim et al., 2019). It was reported that chlormequat chloride used in $\mathrm{G}_{4}$ is also an anti- 
gibberellin , limiting stem elongation and causing height reduction (Rademacher, 2000). Although mepiquat chloride is an onium-type compound similar to chlormequat chloride, it did not reduce the height as effectively as the other two retardants.

\section{Influence of bioregulators on number of fruits of TNAU Papaya C0.8}

When the main effect of bioregulators are considered, a significantly more number of fruits were observed in $\mathrm{G}_{2}$ (38.88) among growth retardants and with strobilurins $\left(\mathrm{S}_{4}-37.84\right)$ among the stress tolerance promoting bioregulators (Figure 1 and 2). Increased number of fruits is generally observed in the plants when treated with salicylic acid along with growth retardants. Significantly higher number of fruits were recorded in the treatment combinations involving $250 \mathrm{ppm}$ of prohexadione calcium and 100 ppm of methyl jasmonate $\left(G_{2} S_{2}-42.17\right), 500$ ppm of mepiquat chloride with $100 \mathrm{ppm}$ of salicylic acid $\left(\mathrm{G}_{3} \mathrm{~S}_{3}-42.01\right)$ and $250 \mathrm{ppm}$ of prohexadione calcium with 100 ppm of salicylic acid $\left(\mathrm{G}_{2} \mathrm{~S}_{3}-41.13\right)$ (Table 2) as compared to control.

Table 2. Influence of bioregulators on morphological, fruit physical parameters and PRSV incidence of TNAU Papaya C0.8

\begin{tabular}{|c|c|c|c|c|c|c|}
\hline Treatment & $\begin{array}{l}\text { Plant height at } \\
\text { fruiting }(\mathbf{c m})\end{array}$ & $\begin{array}{l}\text { First Fruiting } \\
\text { height }(\mathbf{c m})\end{array}$ & $\begin{array}{c}\text { Number of } \\
\text { fruits }\end{array}$ & $\begin{array}{l}\text { Fruit length } \\
\text { (cm) }\end{array}$ & $\begin{array}{c}\text { Fruit } \\
\text { circumference }(\mathrm{cm})\end{array}$ & $\begin{array}{c}\text { PRSV } \\
\text { incidence (\%) } \\
\end{array}$ \\
\hline $\mathrm{G}_{1} \mathrm{~S}_{1}$ & 171.25 & 97.10 & 28.44 & 23.16 & 37.96 & $\begin{array}{r}77.77 \\
(61.87)\end{array}$ \\
\hline $\mathrm{G}_{1} \mathrm{~S}_{2}$ & 174.37 & 100.88 & 33.07 & 24.71 & 38.68 & $\begin{array}{r}62.95 \\
(52.51)\end{array}$ \\
\hline $\mathrm{G}_{1} \mathrm{~S}_{3}$ & 175.48 & 98.91 & 30.13 & 25.34 & 39.41 & $\begin{array}{r}55.55 \\
(48.19)\end{array}$ \\
\hline $\mathrm{G}_{1} \mathrm{~S}_{4}$ & 172.30 & 99.89 & 38.01 & 22.82 & 36.13 & $\begin{array}{r}62.95 \\
(52.51)\end{array}$ \\
\hline $\mathrm{G}_{2} \mathrm{~S}_{1}$ & 140.79 & 68.43 & 35.07 & 27.16 & 40.39 & $\begin{array}{r}62.95 \\
(52.51)\end{array}$ \\
\hline $\mathrm{G}_{2} \mathrm{~S}_{2}$ & 147.51 & 69.66 & 42.17 & 26.18 & 38.06 & $\begin{array}{r}55.55 \\
(48.19)\end{array}$ \\
\hline $\mathrm{G}_{2} \mathrm{~S}_{3}$ & 149.27 & 69.05 & 41.13 & 27.11 & 40.07 & $\begin{array}{r}33.33 \\
(35.26)\end{array}$ \\
\hline $\mathrm{G}_{2} \mathrm{~S}_{4}$ & 152.60 & 70.66 & 37.17 & 25.81 & 40.74 & $\begin{array}{r}55.55 \\
(48.19)\end{array}$ \\
\hline $\mathrm{G}_{3} \mathrm{~S}_{1}$ & 150.34 & 81.23 & 33.03 & 27.34 & 41.87 & $\begin{array}{r}70.36 \\
(57.01)\end{array}$ \\
\hline $\mathrm{G}_{3} \mathrm{~S}_{2}$ & 151.08 & 88.37 & 36.34 & 24.34 & 41.44 & $\begin{array}{r}62.95 \\
(52.51)\end{array}$ \\
\hline $\mathrm{G}_{3} \mathrm{~S}_{3}$ & 154.57 & 82.60 & 42.01 & 29.40 & 39.13 & $\begin{array}{r}48.14 \\
(43.93)\end{array}$ \\
\hline $\mathrm{G}_{3} \mathrm{~S}_{4}$ & 153.29 & 81.53 & 38.04 & 25.75 & 38.94 & $\begin{array}{r}48.14 \\
(43.93)\end{array}$ \\
\hline $\mathrm{G}_{4} \mathrm{~S}_{1}$ & 148.90 & 69.71 & 32.16 & 27.30 & 37.56 & $\begin{array}{r}70.36 \\
(57.01)\end{array}$ \\
\hline $\mathrm{G}_{4} \mathrm{~S}_{2}$ & 150.54 & 70.12 & 34.67 & 28.52 & 41.33 & $\begin{array}{r}62.95 \\
(52.51)\end{array}$ \\
\hline $\mathrm{G}_{4} \mathrm{~S}_{3}$ & 144.76 & 68.17 & 31.13 & 29.18 & 46.05 & $\begin{array}{r}40.73 \\
(39.66)\end{array}$ \\
\hline $\mathrm{G}_{4} \mathrm{~S}_{4}$ & 144.02 & 69.56 & 38.17 & 26.68 & 44.25 & $\begin{array}{r}55.55 \\
(48.19)\end{array}$ \\
\hline $\begin{array}{l}\text { Absolute } \\
\text { control mean }\end{array}$ & 168.74 & 102.71 & 30.14 & 25.18 & 38.72 & $\begin{array}{r}77.77 \\
(61.87) \\
\end{array}$ \\
\hline SEd & 2.57 & 1.75 & 0.65 & 1.02 & 2.17 & 2.02 \\
\hline $\mathrm{CD}(0.05)$ & 5.25 & 3.58 & 1.34 & 2.09 & 4.46 & 4.13 \\
\hline
\end{tabular}

(The values in the parenthesis are arc sine transformed)

The reason for an increase in the number of fruits in strobilurins treated plants can be attributed to possible improvement of cytokinin activity leading to the improved synthesis of photosynthetic pigments

$107 \mid 10-12$ | 4 
and promoting source to sink mobilization (Fletcher et al., 2000). The increase in the number of fruits in plants treated with salicylic acid could be due to the modulation of physiological attributes leading to reduced PRSV disease expression during the fruit developmental phase. A similar finding of an increased number of fruits and yield in papaya cv. Red Lady was reported with the application of salicylic acid (150 ppm) at 45 and 120 days after transplanting. This was attributed to increased chlorophyll accumulation, carbonic anhydrase and rubisco activity which in turn accelerated the translocation of assimilates to developing fruits (Devarakonda et al., 2020). Favorable effects of foliar application of salicylic acid in other fruit crops also reported previously lends support to the present observation (Gioushy (2016); Faissal et al., 2014; Ngullie et al., 2014; Kassem et al., 2011and Bindhyachal et al., 2016).

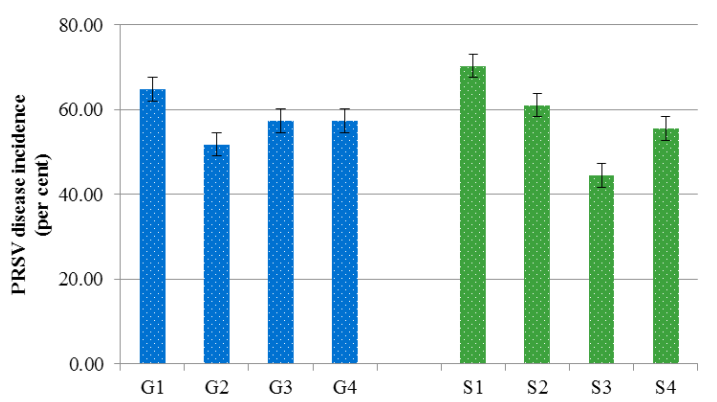

Figure 3. Main effects of bioregulators on PRSV disease incidence

Influence of bioregulators on fruit length and circumference $(\mathrm{cm})$ of TNAU Papaya $\mathrm{CO} .8$

Fruit length and fruit circumference are essential parameters as they positively associate with papain yield by offering more surface area for the extraction of latex (Seemanthini, 1967). In the present study, the combination of $500 \mathrm{ppm}$ of chlormequat chloride with 100 ppm of salicylic acid $\left(G_{4} S_{3}\right)$ resulted in higher fruit length $(29.40 \mathrm{~cm})$ and circumference $(46.05$ $\mathrm{cm}$ ) (Table 2) when compared to other treatments. In all the combinations with chlormequat chloride, the fruits were relatively longer in the present study. This could be due to the enhanced availability of more assimilates to developing fruits as the vegetative growth becomes limited by chlormequat chloride. Besides, the reduction in PRSV symptom expression promoted by stress regulators could have also helped better mobilize available photosynthetic assimilates for fruit development. The main effects of stress regulating growth regulators were not significant on fruit circumference.

\section{Influence of bioregulators on PRSV incidence}

The PRSV incidence at $7^{\text {th }}$ month had a direct bearing on the crop load and yield as the fruit developed was rapid at $7^{\text {th }}$ and $9^{\text {th }}$ month. In the present study, the PRSV disease severity ranged from 33.33 per cent $\left(G_{2} S_{3}\right)$ to 77.77 per cent $\left(G_{1} S_{1}\right.$ and Absolute control mean) at the seventh month after transplanting (Table 2). When the main effects are considered, among the growth retardants, 250 ppm of prohexadione calcium $\left(\mathrm{G}_{2}-51.85 \mathrm{per}\right.$ cent) and salicylic acid at $100 \mathrm{ppm}\left(\mathrm{S}_{3}-44.44\right.$ per cent) resulted in significantly lower PRSV disease incidences (Figure 3). Among the treatment combinations, the lowest disease incidence was recorded in the combination of $250 \mathrm{ppm}$ of prohexadione calcium with $100 \mathrm{ppm}$ of salicylic acid $\left(G_{2} S_{3}-33.33\right.$ per cent), while the incidence was significantin water sprayed plants $\left(G_{1} S_{1}-77.77\right.$ per cent). The reduced disease expression of PRSV in prohexadione calcium treated plants could be attributed to the content of calcium, which is known to provide integrity to cell wall and membrane ,thus possibly delaying early degeneration during the pathogen infection. It has been reported that exogenous calcium supply improved the plant's resistance, including virus infection (Eraslan et al., 2007 and Thor, 2019). In general, the plants sprayed with salicylic acid showed low incidence of PRSV when compared with other treatments. Salicylic acid has been known to induce resistance to viruses and inhibit the development of viral diseases in plants (Naylor et al., 1998). In an earlier study, Guan (2007) reported that improved resistance to PRSV by salicylic acid application. As PRSV drastically reduces fruit production and markedly reduces papain production (Khurana, 1970 and Singh et al., 2005), spraying with 100 ppm of salicylic acid could be recommended to manage the disease either for fruit production and papain extraction in combination with prohexadione calcium.

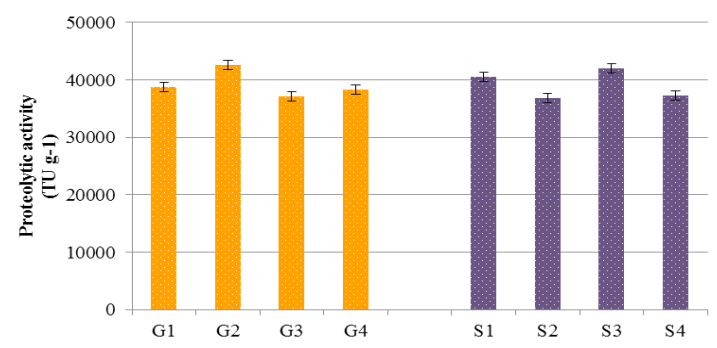

Figure 4. Main effects of bioregulators on proteolytic activity (TU g-1)

\begin{tabular}{ll}
\hline Factor 1: Growth retardants & $\begin{array}{c}\text { Factor 2: Bioregulators for } \\
\text { stress tolerance }\end{array}$ \\
\hline $\mathrm{G}_{1}-$ Control ( water & $\mathrm{S}_{1}-$ Control (water spray); \\
spray); $\mathrm{G}_{2}-250 \mathrm{ppm}$ of & $\mathrm{S}_{2}-100 \mathrm{ppm}$ of methyl \\
pro hexadione calcium; & Jasmonate; $\mathrm{S}_{3}-100 \mathrm{ppm}$ \\
$\mathrm{G}_{3}-500$ ppm of mepiquat & of salicylic acid; $\mathrm{S}_{4}-0.6 \mathrm{~g} /$ \\
chloride; $\mathrm{G}_{4}-500$ ppm of & $\mathrm{L}$ of strobilurins \\
chlormequat chloride & \\
\hline
\end{tabular}




\section{Influence of bioregulators on wet latex yield of TNAU Papaya C0.8}

When the main effects are considered, among the growth retardants, significantly higher wet latex yield were recorded by $250 \mathrm{ppm}$ of prohexadione calcium $\left(G_{2}-26.40 \mathrm{~g} \mathrm{fruit}^{-1}\right)$ and $500 \mathrm{ppm}$ of mepiquat chloride $\left(G_{3}-26.29\right.$ g fruit $\left.^{-1}\right)$. Similarly, 100 ppm of salicylic acid $\left(S_{3}-32.60\right.$ g fruit $\left.^{-1}\right)$ treated plants registered higher wet latex yield among the stress tolerance promoting bioregulators (Figure 5a). Among the combinations, the highest wet latex yield was recorded in plants sprayed first with water spray and a week later with100 ppm of salicylic acid $\left(\mathrm{G}_{1} \mathrm{~S}_{3}\right.$ - $42.08 \mathrm{~g} \mathrm{fruit}^{-1}$ ), indicating the beneficial effect of salicylic acid. It was followed by the combinations 250 ppm of prohexadione calcium in combination with either $100 \mathrm{ppm}$ of salicylic acid $\left(\mathrm{G}_{2} \mathrm{~S}_{3}-33.45\right.$ $\mathrm{g}$ fruit $\left.^{-1}\right)$ or just water spray $\left(\mathrm{G}_{2} \mathrm{~S}_{1}-33.14 \mathrm{~g}_{\text {fruit }}{ }^{-1}\right)$ (Table 3).

Table 3. Influence of bioregulators on wet, dry latex yield (g) and papain proteolytic activity (TU $\left.\mathrm{g}^{-1}\right)$ of TNAU Papaya C0.8

\begin{tabular}{|c|c|c|c|c|c|c|}
\hline Treatment & $\begin{array}{l}\text { wet latex yield/ } \\
\text { fruit (g) }\end{array}$ & $\begin{array}{c}\text { Dry latex } \\
\text { yield/ fruit (g) }\end{array}$ & $\begin{array}{c}\text { wet latex yield/ } \\
\text { tree (g) }\end{array}$ & $\begin{array}{c}\text { Dry latex yield/ } \\
\text { tree (g) }\end{array}$ & $\begin{array}{c}\text { Ratio of dry and } \\
\text { wet latex yield }\end{array}$ & $\begin{array}{c}\text { Proteolytic } \\
\left.\text { activity (TU g }{ }^{-1}\right)\end{array}$ \\
\hline $\mathrm{G}_{1} \mathrm{~S}_{1}$ & 22.84 & 3.05 & 649.35 & 86.70 & 0.13 & 39296.16 \\
\hline $\mathrm{G}_{1} \mathrm{~S}_{2}$ & 11.57 & 0.97 & 382.61 & 31.94 & 0.08 & 34916.58 \\
\hline $\mathrm{G}_{1} \mathrm{~S}_{3}$ & 42.08 & 7.39 & 1268.04 & 222.81 & 0.18 & 44178.21 \\
\hline $\mathrm{G}_{1} \mathrm{~S}_{4}$ & 13.49 & 2.33 & 512.82 & 88.67 & 0.17 & 36813.92 \\
\hline $\mathrm{G}_{2} \mathrm{~S}_{1}$ & 33.14 & 6.34 & 1161.97 & 222.36 & 0.19 & 44378.15 \\
\hline $\mathrm{G}_{2} \mathrm{~S}_{2}$ & 19.13 & 4.57 & 806.82 & 192.87 & 0.24 & 41693.22 \\
\hline $\mathrm{G}_{2} \mathrm{~S}_{3}$ & 33.45 & 5.17 & 1376.07 & 212.66 & 0.15 & 44378.36 \\
\hline $\mathrm{G}_{2} \mathrm{~S}_{4}$ & 19.89 & 2.18 & 739.32 & 81.10 & 0.11 & 40112.17 \\
\hline $\mathrm{G}_{3} \mathrm{~S}_{1}$ & 26.68 & 5.36 & 881.40 & 177.03 & 0.20 & 39168.37 \\
\hline $\mathrm{G}_{3} \mathrm{~S}_{2}$ & 24.92 & 5.11 & 905.62 & 185.83 & 0.21 & 34108.23 \\
\hline $\mathrm{G}_{3} \mathrm{~S}_{3}$ & 27.87 & 6.28 & 1170.95 & 263.63 & 0.23 & 39794.04 \\
\hline $\mathrm{G}_{3} \mathrm{~S}_{4}$ & 25.69 & 5.29 & 977.24 & 201.06 & 0.21 & 35281.19 \\
\hline $\mathrm{G}_{4} \mathrm{~S}_{1}$ & 24.87 & 5.23 & 800.00 & 168.25 & 0.21 & 39452.18 \\
\hline $\mathrm{G}_{4} \mathrm{~S}_{2}$ & 17.52 & 2.16 & 607.43 & 74.81 & 0.12 & 36781.08 \\
\hline $\mathrm{G}_{4} \mathrm{~S}_{3}$ & 26.98 & 6.22 & 840.10 & 193.56 & 0.23 & 39896.67 \\
\hline $\mathrm{G}_{4} \mathrm{~S}_{4}$ & 21.91 & 3.09 & 836.04 & 118.05 & 0.14 & 36917.37 \\
\hline $\begin{array}{l}\text { Absolute control } \\
\text { mean }\end{array}$ & 24.18 & 4.34 & 673.33 & 120.92 & 0.18 & 38726.26 \\
\hline SEd & 1.61 & 0.31 & 25.27 & 4.63 & 0.01 & 785.37 \\
\hline CD (0.05) & 3.31 & 0.64 & 51.61 & 9.46 & 0.02 & 1603.96 \\
\hline
\end{tabular}

As similar to wet latex yield per fruit, the combination of $250 \mathrm{ppm}$ of prohexadione calcium along with 100 ppm of salicylic acid $\left(\mathrm{G}_{2} \mathrm{~S}_{3}-1376.07\right.$ $\mathrm{g} \mathrm{tree}^{-1}$ ) recorded the highest wet latex yield per tree. The combination of $100 \mathrm{ppm}$ of methyl jasmonate with $500 \mathrm{ppm}$ of mepiquat chloride resulted in a moderately higher quantity of wet latex yield $\left(\mathrm{G}_{3} \mathrm{~S}_{2}\right.$ $905.62 \mathrm{~g}$ tree $^{-1}$ and $\mathrm{G}_{3} \mathrm{~S}_{4}-977.24 \mathrm{~g}_{\text {tree }}{ }^{-1}$ ), but when methyl jasmonate was combined with water spray $\left(G_{1} S_{2}\right)$ latex yield was lower than control, indicating methyl jasmonate may be detrimental for papain production. Although methyl jasmonate is known for imparting defense mechanisms against many biological stresses in plants (Ahmad et al., 2016), its utility in papaya for managing PRSV should be weighed carefully as the papain yield gets reduced.

The possible higher and improved availability of calcium contributed by prohexadione calcium could also be influential in higher papain latex yield as calcium is responsible for cell wall integrity and protecting the lactiferous cells and channels from disintegration due to PRSV. In the combinations involving salicylic acid,a higher amount of wet latex was observed generally in the present study. Besides the induced resistance, the phenolic nature of salicylic acid may promote the expression of the cysteine protease gene which is responsible for the production of papain (Kovacs et al., 2016). 


\section{Influence of bioregulators on dry latex yield of TNAU Papaya C0.8}

Dry latex yield per fruit was also significantly influenced by the foliar application of bioregulators (Table 3). Among the growth retardants, 500 ppm of mepiquat chloride $\left(\mathrm{G}_{3}-5.51 \mathrm{~g}\right.$ fruit $^{-1}$ and 206.89 $\mathrm{g} \mathrm{tree}^{-1}$ ) recorded higher dry latex yield.

While considering the stress tolerance promoting bioregulators, $100 \mathrm{ppm}$ of salicylic acid $\left(\mathrm{S}_{3}\right)$ recorded the highest dry latex yield $\left(6.27 \mathrm{~g} \mathrm{fruit}^{-1}\right.$ and $223.17 \mathrm{~g}$ tree $^{-1}$ ) and the lowest dry latex yield (3.20 g fruit $^{-1}$ and 121.36 g tree $^{-1}$ ) was recorded in 100 ppm of methyl jasmonate treated fruits $\left(S_{2}\right)$ (Figure $5 b$ and $5 d$ ).

Among the combinations, a higher quantity of dry latex per fruit (7.39 $\mathrm{g}$ fruit $^{-1}$ ) was recorded in $\mathrm{G}_{1} \mathrm{~S}_{3}$ combinations (water with 100 ppm of salicylic acid) and it was followed by the combinations $250 \mathrm{ppm}$ of prohexadione calcium with water $\left(\mathrm{G}_{2} \mathrm{~S}_{1}-6.34 \mathrm{~g}\right.$ fruit $^{-1}$ ), 500 ppm of mepiquat chloride with 100 ppm of salicylic acid $\left(\mathrm{G}_{3} \mathrm{~S}_{3}-6.28 \mathrm{~g} \mathrm{fruit}^{-1}\right)$ and $500 \mathrm{ppm}$ of chlormequat chloride with 100 ppm of salicylic acid $\left(G_{4} S_{3}-6.22\right.$ g fruit $\left.^{-1}\right)$. As the wet latex yield was found to be more in salicylic acid and prohexadione calcium treated plants, the dry latex yield per fruit was also proportionately higher in these treatments.

Among the combinations, application of mepiquat chloride (500 ppm) and salicylic acid (100 ppm) at fourth and eighth month after transplanting significantly increased the dry latex yield per tree $\left(\mathrm{G}_{3} \mathrm{~S}_{3}-263.63 \mathrm{~g}_{\text {tree }}{ }^{-1}\right)$ as compared to control. Prohexadione calcium $\left(\mathrm{G}_{2}\right)$ or salicylic acid $\left(\mathrm{S}_{3}\right)$ yielded moderately higher content of dry latex per tree (222.36 and $222.81 \mathrm{~g}$ tree $\left.^{-1}\right)$ when it was combined with water. The estimated yield of dry latex per acre was also higher $\left(\mathrm{G}_{3} \mathrm{~S}_{3}-210.91 \mathrm{~kg}\right.$ acre $\left.^{-1}\right)$ in the combination $500 \mathrm{ppm}$ of mepiquat chloride with 100 ppm of salicylic acid (Figure 6).

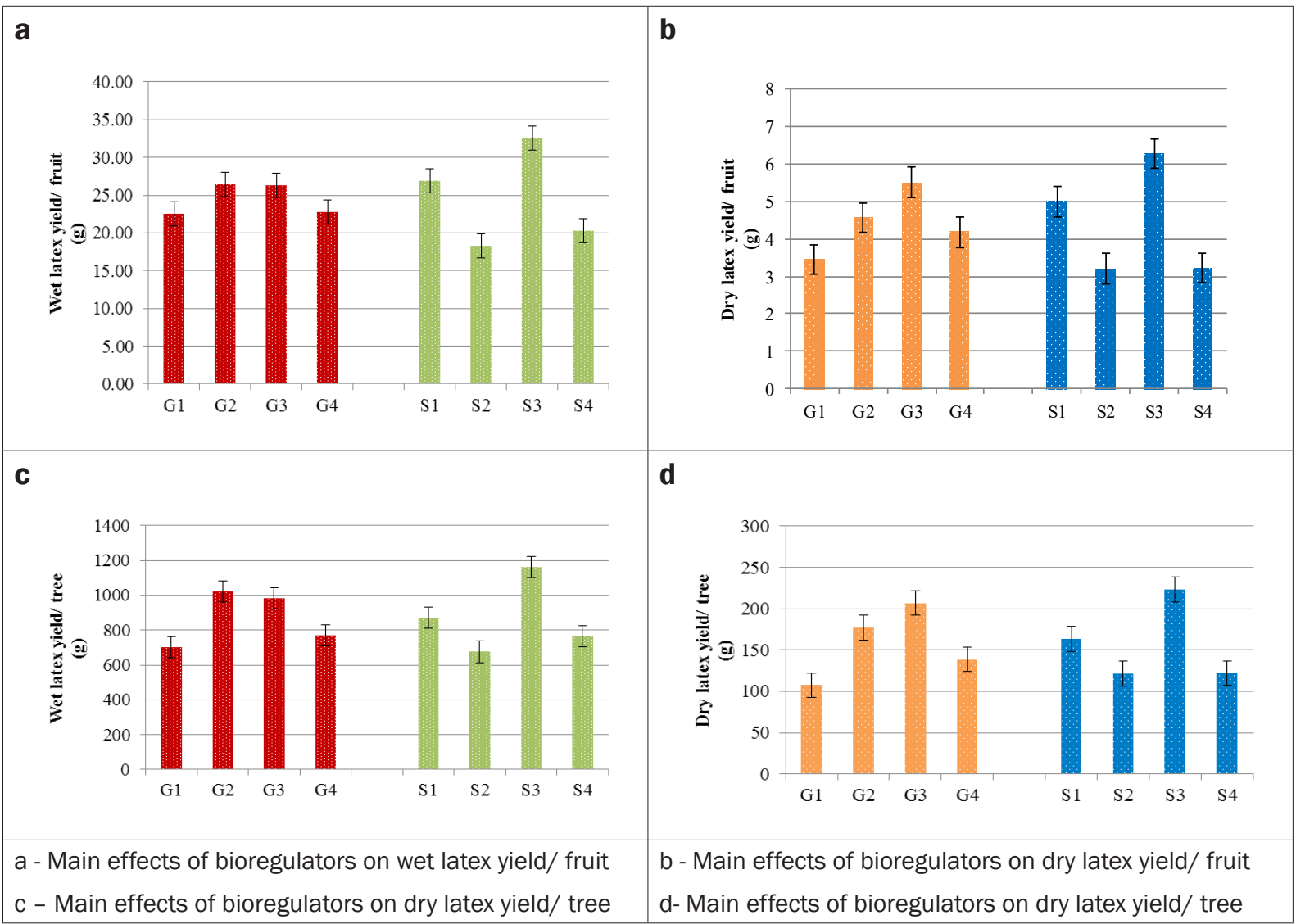

Figure 5. Main effects of bioregulators on wet, dry latex yield (g) and proteolytic activity (TU $\mathrm{g}^{-1}$ )

In the present study, foliar application of methyl jasmonate $\left(G_{1} S_{2}\right)$ was found to limit the dry latex yield (31.94 $\mathrm{g} \mathrm{tree}^{-1}$ ) as the wet latex yield itself was reduced. Application of jasmonate or its methyl ester was reported to strongly induce local and systemic expression of protease inhibitor genes in a variety of plant species (Koiwa et al., 1997) and whether such inhibitory process is involved in papain yield as in the present study needs to be further explored.

\section{Influence of bioregulators on proteolytic activity $\left(T U g^{-1}\right)$}

Among the growth retardants, higher proteolytic activity was observed in 250 ppm of prohexadione calcium $\left(\mathrm{G}_{2}-42640.48 \mathrm{TU} \mathrm{g}^{-1}\right)$ and in stress tolerance promoting bioregulators, $100 \mathrm{ppm}$ of salicylic acid recorded the highest proteolytic activity $\left(\mathrm{S}_{3}\right.$ 42061.82 TU g-1 $^{-1}$ ) (Figure 4). 
In the treatment with prohexadione calcium alone or in combination with salicylic acid higher proteolytic activity $\left(\mathrm{G}_{2} \mathrm{~S}_{1}-44378.15 \mathrm{TU} \mathrm{g}^{-1}, \mathrm{G}_{1} \mathrm{~S}_{3}\right.$ 44178.21 $\mathrm{TU} \mathrm{g}^{-1}$ and $\mathrm{G}_{2} \mathrm{~S}_{3}$ - 44378.36 TU g ${ }^{-1}$ ) (Table 3 ) were recorded. However, the dry papain yield was comparatively lower in these treatments as compared to $\mathrm{G}_{3} \mathrm{~S}_{3}$. The proteolytic activity of the dry papain recovered from the treatment $\mathrm{G}_{3} \mathrm{~S}_{3}$ was moderate (39794.04 $\mathrm{TU}^{-1}$ ) but the number of fruits and papain yield was higher, this combination would be commercially more beneficial as compared to other treatments. Although in $\mathrm{G}_{2} \mathrm{~S}_{2}$ and $\mathrm{G}_{3} \mathrm{~S}_{2}$, the number of fruits were comparable to $\mathrm{G}_{3} \mathrm{~S}_{3}$ and plant heights were moderately lower, these treatment combinations fared poorer than $\mathrm{G}_{3} \mathrm{~S}_{3}$ for dry latex yield per tree. In the other treatment combinations, either the papain recovery was low or the papain activity was not high. The fruit yield was also not as high as $\mathrm{G}_{3} \mathrm{~S}_{3}$ in the other combinations.

Application of $500 \mathrm{ppm}$ of mepiquat chloride at fourth and eighth month after transplanting followed by a spray of 100 ppm of salicylic acid could help to achieve a higher dry latex yield, moderately high proteolytic activity with a significant reduction in PRSV symptoms. In economic terms, the growers need a balance between fruit yield as well as papain yield. Since the income derived from fruit yield is primary, considering the overall yield as well as moderately high dry latex yield (papain recovery), this treatment has to be further manipulated to achieve the higher proteolytic activity.

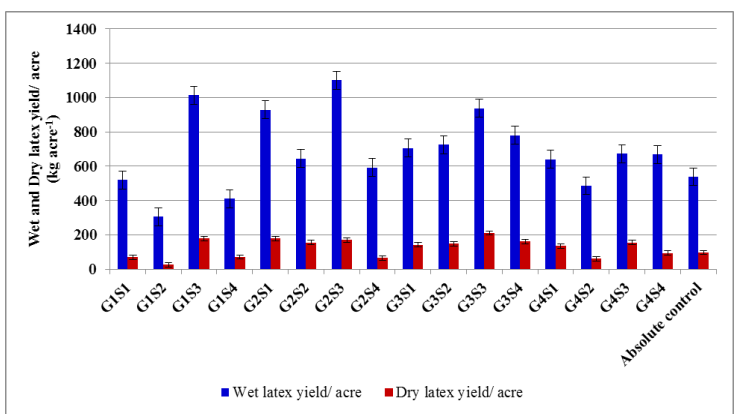

Figure 6. Influence of bioregulators on wet and dry latex yield $\left(\mathrm{kg} \mathrm{acre}^{-1}\right)$ of TNAU Papaya c0.8

\begin{tabular}{|c|c|}
\hline $\begin{array}{l}\text { Factor 1: Growth } \\
\text { retardants }\end{array}$ & $\begin{array}{c}\text { Factor 2: Bioregulators for } \\
\text { stress tolerance }\end{array}$ \\
\hline $\begin{array}{l}\mathrm{G}_{1}-\text { Control ( water } \\
\text { spray); } \mathrm{G}_{2}-250 \text { ppm of pro } \\
\text { hexadione calcium; } \mathrm{G}_{3}-500 \\
\text { ppm of mepiquat chloride; } \\
\mathrm{G}_{4}-500 \text { ppm of chlormequat } \\
\text { chloride }\end{array}$ & $\begin{array}{l}\mathrm{S}_{1}-\text { Control (water spray); } \\
\mathrm{S}_{2}-100 \mathrm{ppm} \text { of methyl } \\
\text { Jasmonate; } \mathrm{S}_{3}-100 \mathrm{ppm} \text { of } \\
\text { salicylic acid; } \mathrm{S}_{4}-0.6 \mathrm{~g} / \mathrm{L} \text { of } \\
\text { strobilurins }\end{array}$ \\
\hline
\end{tabular}

\section{CONCLUSION}

Considering the remarkable reduction of PRSV disease incidence as compared to control, moderate tree height coupled with a higher number of fruits and higher papain activity which are primary deciding factors in generating farmers income, the treatment combination of $250 \mathrm{ppm}$ of prohexadione calcium with $100 \mathrm{ppm}$ of salicylic acid $\left(\mathrm{G}_{2} \mathrm{~S}_{3}\right)$ can be adjudged as favorable treatment for fruit and papain production. The results also shows that the treatment of $500 \mathrm{ppm}$ of mepiquat chloride at the fourth and eighth month after transplanting followed by a spray of $100 \mathrm{ppm}$ of salicylic acid $\left(\mathrm{G}_{3} \mathrm{~S}_{3}\right)$ is favorable to achieve higher yield and effectively reduce PRSV incidence, but the proteolytic activity of papain is moderate in this treatment, and hence this combination could be effective when papayas are predominantly grown for fruits (table purpose) and not necessarily for papain. These two treatment combinations $\left(G_{2} S_{3}\right.$ and $\left.G_{3} S_{3}\right)$ are to be further studied for their effects on the post-harvest quality of fruits and as well as on different varieties of papaya to manage PRSV without compromising yield and papain production.

\section{REFERENCES}

Abdi, S., Abbaspur, N., Avestan, S. and A.V.Barker. 2016. Sana physiological responses of two grapevine (Vitis vinifera L.) cultivars to Cycocel ${ }^{\mathrm{TM}}$ treatment during drought. The J Hort. Sci. Biotechnol., 91(3):211-219.

Azarkan, M., Moussaoui, A.E. Wuytswinkel, D.,Dehon, G. and Y. Looze. 2003. Fractionation and purification of the enzymes stored in the latex of Carica papaya. J. Chrom. B., 790: 229-238.

Ahmad, P., Rasool, S., Gul, A., Sheikh, S.A., Akram, N.A., Ashraf, M., Kazi, A.M. and S. Gucel. 2016.. Jasmonates: multifunctional roles in stress tolerance. Frontiers in pl. sci., 7:813.

Bindhyachal R., Bipul K. M., Kumar,U., and R. K. P. Kumar. 2016. Response of Guava to Boron and Growth Regulators Spray. Asian J Hort., 11(1):146-150.

Bolter C. J. 1993. Methyl Jasmonate Induces Papain Inhibitor(s) in Tomato Leaves. PI Physiol., 103(4):1347-1353. doi: 10.1104/ pp.103.4.1347.

Devarakonda, S., Madhumathi, C., Umamahesh, V., Mukunda, L., Lakshmi, M., Bhaskar, V.V. and T. Rajasekharam. 2020. Growth, flowering and yield Response of papaya (Carica papaya L.) cv. red lady to exogenous application of salicylic acid and Jasmonic acid. The Pharma Innovation J., 9(5): 160-165

Dhanam, S. 2006. Studies on papaya ring spot disease. M.Sc. thesis submitted to Tamil Nadu Agric. Univ.

do C. Mouco, M.A., Ono, E.O., Rodrigues, J.D. and G.J.N. Silva. 2010.Plant regulators on vegetative growth of tommy atkins mangoes. In IX International Mango Symposium., 992:187-192

Eraslan, F., Akbas, B., Inal, A and C. Tarakcioglu. 2017. Effects of foliar sprayed calcium sources on Tomato mosaic virus (ToMV) infection in tomato plants grown in greenhouses. Phytoparasitica., 
35: 150. https://doi.org/10.1007/BF02981110

Faissal, F., Mohamed, A., Kamel, KH. and M. Hamdy. 2014. The Synergistic Effects of Using Plant Extracts and Salicylic Acid on Yield and Fruit Quality of Keitte Mango Trees. Stem Cell., 5(2):30-39

Fletcher, R.A., Gilley, A., Sankhla, N. and T.D, Davis.2000. Triazoles as plant growth regulators and stress protectants. Horti. Reviews., 24:55-138.

Gioushy S.F.E. 2016.Productivity, fruit quality and nutritional status of Washington navel orange trees as influenced by foliar application with salicylic acid and potassium silicate combinations.. J Hort. Sci. Orn. Plants., 8(2):98-107.

Gonsalves, D., Tripathi, S., Carr, J. B., and J. Y. Suzuki. 2010. Papaya ringspot virus. The Plant Health Instructor., 10: 1094.

Guan, Z. 2007.Effect of Salicylic Acid on Papaya Ringspot Virus Disease. Chinese J.Tropical Agric., (https://www.semanticscholar.org/paper/Effectof-Salicylic-Acid-on-Papaya-Ringspot-Virus-Guan/1b 7ce4bb84d502b399604c9e62a68f9ec5e2652e)

Kassem, H. A., Al-Obeed, R. S., Ahmed, M. A. and A. K. H. Omar. 2011. Productivity, fruit quality and profitability of jujube trees improvement by preharvest application of agro-chemicals. Middle-East. J. Sci. Res., 9(5):628-637.

Khurana S. M. P. 1970. Effect of virus diseases on the latex and sugar contents of papaya fruits. J. Hort. Sci.,45: 295-7.

Kim, H.M., Lee, H.R., Kang, J.H. and S. J. Hwang. 2019. Prohexadione-calcium application during vegetative growth affects growth of mother plants, runners, and runner plants of Maehyang strawberry. Agronomy., 9(3) :155.

Koiwa, H., Bressan, R. A. and P. M. Hasegawa. 1997. A review: Regulation of protease inhibitors and plant defense. Trends pl. sci., 2 (10); 379-384

Kovacs, J., Poor, P., Szepesi, A. and I. Tari. 2016. Salicylic acid induced cysteine protease activity during programmed cell death in tomato plants. Acta Biologica Hungarica., 67(2): 148158. doi:10.1556/018.67.2016.2.3

Le Roux, S. and G.H.Barry. 2010. Vegetative growth responses of citrus nursery trees to various growth retardants. Hort Technol., 20(1): 197-201.

Mamboya, E.A.F.2012. Papain, a plant enzyme of biological importance: a review. American $J$. Biochem and Biotechnol., 8(2): 99-104.

Mishra R., Patil S., Patil A. and B. L. Patil. 2019. Sequence diversity studies of papaya ringspot virus isolates in South India reveal higher variability and recombination in the 5'-terminal gene sequences.
Virus disease., 30(2):261-268. doi: 10.1007/ s13337-019-00512-x.

Naylor, M.,. Murphy, A. M Berry J. O. and J. P. Carr. 1998. Salicylic Acid Can Induce Resistance to Plant Virus Movement. Mol. PI. Microbe Interactions., 11 (9): 860-868

Ngullie, C.R., TankT. V and D. R. Bhanderi.2014. Effect of salicylic acid and humic acid on flowering, fruiting, yield and quality of mango (Mangifera indica L.) cv. Kesar. Adv. Res. J. Crop improvement., 5(2):136-139.

Puig, A., Gil,I. and O. Sanchez. 2008. Evaluation of drying techniques measuring proteolytic activity of papain obtained from unripe fruit and skin juice. Ind. Biotech. Intern. Conference. June 8-11, Italy.

Rademacher, W. 2000. Growth retardants : Effects on Gibberellin Biosynthesis and Other Metabolic Pathways. Annu. Rev. Plant Physiol. Plant Mol. Biol., 51:501-31

Seemanthini, B. 1964. A study of the influence of fruit size on the yield of papain in certain inbred selections of papaya (Carica papaya L.). Indian J. Hort., 24 : 141-154.

Shouket, H.A., Ameen, I., Tursunov, O., Kholikova, K., Pirimov, O., Kurbonov, N., Ibragimov, I. and B. Mukimov. 2020. Study on industrial applications of papain: A succinct review. In IOP Conference Series: Earth and Environmental Science., 614(1). IOP Publishing.

Singh, V.and K.Shukla 2009. Effect of PRSVinfection on pigment content and assimilation of carbohydrates on Carica papaya. Ann. Pl. Protec. Sci., 17: 152-156.

Singh, Rao G. P. and K. Shukla. 2005. Response of commercially important papaya cultivars to papaya ringspot virus in eastern U.P. conditions. Indian Phytopathol., 58(2): 212-6.

Song, Y. J., Yu, H. H. Kim, Y. J. Lee N. K. and H. D. Paik. 2020. The use of papain for the removal of biofilms formed by pathogenic Staphylococcus aureus and Campylobacter jejuni. LWT - Food Sci. Technol., $127-109383$

Thor, K. 2019. Calcium-Nutrient and messenger. Frontiers in pl. sci., 10: 440.

Varisha, A., Husain, A. S. Javed, N. K. and A. Poonam. 2013. Physico-chemical and phytochemical evaluation of Carica papaya Linn. Unripe fruits. Int. Res. J. Pharm., 4(8): $101-106$.

Weissler, H.E and A.C. Garza. 1965. Some physical and chemical properties of commercial chillproofing compounds. A.S.B.C. Proc..,225-228. 